\title{
The Effect of Environmental Performance and Intellectual Capital on Financial Performance Moderated by CSR Disclosure on Manufacture Companies Listed in ISX
}

\author{
Azhar Maksum \\ Faculty of Economic and Business \\ Universitas Sumatera Utara \\ Medan, Indonesia \\ azharmaksum16@gmail.com
}

\author{
Paula Tamba \\ Faculty of Economic and Business \\ Universitas Sumatera Utara \\ Medan, Indonesia \\ paulatamba@gmail.com
}

\begin{abstract}
This study aims to analyze the effect of environmental performance and intellectual capital on the financial performance of companies moderated by corporate social responsibility disclosure. Data are collected from all manufacturing companies listed on the Indonesia Stock Exchange in 2012-2014. By using the purposive sampling method, from 143 companies manufacturing companies 42 were selected as a sample. This research was designed as causal associative research. The analysis technique used in this study is a multiple linear regression analysis with interaction analysis used to analysis whether a variable moderating able to influence the interaction relationship between independent variable and the dependent variable. The result showed that the environmental performance and the intellectual capital simultaneously have a significant effect on financial performance, however, partially only intellectual capital has significant effect on financial performance. Lastly, corporate social responsibility disclosure could not moderate the effect of environmental performance and intellectual capital on financial performance.
\end{abstract}

Keywords-Financial performance; environmental performance; intellectual capital; VAIC; CSR disclousure

\section{INTRODUCTION}

Financial performance is an achievement of the company as contained in the financial statements [1] which can also reflect the company's health level [2]. The main point in assessing the company's financial performance is the company's ability to earn profits because profit plays an important role in maintaining the viability of the company [3] and also as a guide for prospects [4]. With the profits earned the company will be able to increase its growth and maintain its survival and can provide returns in the form of dividends to shareholders.

Every company has an interest in measuring its financial performance. For external parties, financial performance can be used as a benchmark in assessing the company's financial success [5]. If the company's financial performance is good, then it will generate investor confidence to invest its capital so as to increase the value of the company [6]; [7]. From a management point of view, financial performance is also a representation of the results of many individual decisions made continuously by management [8]. Therefore, the measurement of this financial performance will be an input for future improvement of operational activities and strategies [9]. Management can use it in evaluating both the poor decisions made and the implementation of those decisions and the strategies it has chosen. Thus it can certainly be used as a basis for determining corporate strategy in the future and can provide guidance in decision making and organizational activities in general and the basis in determining policies in order to improve the efficiency and productivity of the company.

There are many factors that affect the company's financial performance, both internal factors, such as liquidity [10], leverage [11] and external. Of the various factors, the company's concern to the environment and intellectual capital factor of the company is a factor that in the recent attention is very interesting and still not much studied. Corporate awareness in the field of environmental management can provide added value for the company that will impact on company performance. According to [12] that the company's activities in the field of environmental conservation will bring a number of advantages, including the interest of shareholders and stakeholders to corporate profits due to responsible environmental management. Likewise, with the rapid development of science and technology, intellectual capital has been regarded as a crucial factor in corporate success [13]. To achieve success or produce a high and stable financial performance 
companies must change their business strategy from laborbased to knowledge base in order to compete with other companies.

Research on the relationship between environmental performance and the financial performance of the company has been done by several researchers, among others [14], [15], and [16] who found no influence of environmental performance on financial performance. On the contrary, several other studies have found significant effects, such as [17], [18]. Research that connects intellectual capital and financial performance has also been done by [19], and [18] found that intellectual capital had no effect on financial performance, while other researchers, such as [20], [21], [22], [23], and [24] found that intellectual capital had a positive influence on financial performance.

Starting from the background mentioned above, this study aims to analyze and prove how the influence of environmental performance and intellectual capital of the company on financial performance by also involving other variables, namely the disclosure of social responsibility (corporate social responsibility disclosure) as a moderating variable. In this study, manufacturing companies listed on the Indonesia Stock Exchange serve as the object of research.

\section{LITERATURE REVIEW HYPOTHESES DEVELOPMENT}

AND

\section{A. Financial Performance}

Performance is a description of the level of achievement (achievement) the implementation of a company's activities in realizing the means, goals, mission, and vision of the organization depends on strategic planning of a company [25]. While the financial performance according to [26] is a measure of corporate achievement in a certain period. The financial performance of the company is contained in the company's financial statements. To find out how the company's financial performance, various financial ratios must be accessed from its financial statements. These ratios link the various figures presented in the financial statements.

Although there are various financial ratios by performing financial statement analysis [27], but the actual ratio can illustrate the good/bad financial performance of the company is the ratio of profitability (profitability ratio). This ratio shows the company's ability to generate profits. The profitability ratio can consist of Gross Profit Margin, Net Profit Margin, Return on Assets, Return on Equity, and Operating Ratio. Because the success of a company is not only seen from the amount of profit it produces but also must be connected with the capital used to obtain the intended profit, the better profitability ratio is used [28] is Return on Assets (ROA ). With ROA, the company's financial performance not only illustrates its ability to generate profits but also can describe the level of effectiveness and efficiency in using the assets owned and also the debt it uses [29] and therefore more often used by investors in investment decision making.
There are many factors that can affect the financial performance of the company. These factors are of a general nature that can apply to all firms, but some are applicable only to certain companies. Factors such as leverage [11]; [30], growth [31]; [32], firm size [33]; [34] as well as liquidity [35]; [30] are factors that have been found to have an effect on the financial performance of the company in general. For certain types of companies, certain factors are found to affect its performance, but they are not found in other types of companies. For example, the operational cost ratio with operating income or BOPO [36]; [37] and the bank's management capability in managing Non-Performing Loan [38], [39] are examples of factors that only influential found specifically in companies engaged in banking services.

Furthermore, the company's concern on environmental management by [12], also [40] will be able to provide added value to the company because it can bring a number of advantages, such as raising the interest of shareholders and stakeholders to invest. This form of awareness can be described by the company's environmental performance. Research conducted by [41] and also [42] has found the relationship between environmental performance and financial performance. So is the case with the intellectual capital factor that is non-physical capital, either in the form of information or knowledge applied to create value for the company [21]. This intellectual capital plays an important role in improving the competitiveness of enterprises and is very effective in increasing corporate profits [43]. This study focuses only on the influence of these last two factors, namely environmental performance and intellectual capital on financial performance.

\section{B. Environmental Performance}

As stated by [44] that the concept of environmental performance refers to the level of environmental damage caused by the activities of the company, where the low level of damage shows good environmental performance and vice versa. This is in line with [42] stating that the company's environmental performance is the company's performance in creating a green environment in which environmental performance includes several aspects related to company operations, such as raw materials, energy, water, biodiversity, emissions, rivers, garbage, suppliers and services, implementation and transportation. In achieving business success environmental performance is one important step. For Indonesia, this environmental performance is measured by the company's achievement following the PROPER program (Corporate Performance Rating Program in Environmental Management). This program is one of the efforts undertaken by the Ministry of Environment since 1995 in encouraging corporate 
compliance in environmental management. PROPER results are announced regularly to the public so that the company's reputation level depends on the level of corporate compliance with its environmental management rules.

In this case, the company's environmental performance rating is grouped into five ratings marked with different colors to facilitate communication with stakeholders in addressing the performance results of each company's compliance. The use of color rankings is a communicative form of delivering environmental performance to the community, so it is easier to understand and remember. The five color ratings used include black, red, blue, green, and gold. Golden and green ratings are awarded to companies that have made more obedient efforts in environmental management and should serve as examples for other companies, blue ratings are awarded to companies that have been adhered to, and red and black ratings are awarded to companies that have not yet adhered to environmental management rules.

[41] has tried to examine the relationship between environmental disclosure, environmental performance and the economic performance of the firm. The findings indicate a positive and significant relationship between environmental performance and financial performance. Further research conducted by [42] in manufacturing companies listed on the BEI have also found that the company's concern in the field of environmental management can provide added value for the company, so it can be concluded that a good environmental performance will also improve the company's financial performance. Similarly, studies conducted by [17] and [18] have found that environmental performance is positively and significantly related to financial performance. The better the company's environmental performance will be the higher the financial performance. Nevertheless, there are also several studies that find results that differ from the above findings, such as [14], [15], and [45]. Their research has found that environmental performance has no effect on the company's financial performance.

\section{Intellectual Capital}

Intellectual capital refers to non-physical capital or intangible assets or invisible. In explaining the understanding of intellectual capital the experts divide it into the potential wealth of companies stored in human resources [46, always referred to as human capital, also stored in the organization and its management [47], referred to as structural capital, as well as those stored in the relationships built by the company [13] are referred to as relational capital or customer capital. According to [46] further, companies that have knowledgeable human resources, skilled, and have the ability to complete tasks well, let alone be able also to innovate will be able to produce a good performance and will clearly support the company achieve financial performance maximum anyway. Furthermore, companies that have a wealth of organization and management, among others, include good information systems and procedures, organizational culture, and management philosophy will have an advantage in the implementation of various processes that exist in the organization so that will be able to achieve optimal performance [19]. Likewise, a company is very possible to achieve optimal financial performance when successfully established and have good relationships with parties outside the company such as government, markets, suppliers, and customers.

From the above description can be concluded that the intellectual capital owned by a company will be able to increase the financial performance of the company. Several previous studies have proven the positive influence of this intellectual capital on financial performance. For example, the research of [48] and [21] concluded that intellectual capital was able to increase the company's financial performance. In Indonesia, research by [22] on a number of manufacturing companies listed on the Indonesia Stock Exchange found that intellectual capital has a significant positive effect on the performance of the company today and in the future as well as the average growth of intellectual capital has a significant positive effect on company performance in the future. Similarly, [24] research conducted on state-owned companies listed on the Indonesia Stock Exchange also found that intellectual capital affects the company's financial performance. Nevertheless, there are also some studies that do not find any influence of or relationship between intellectual capital with the company's financial performance. For example, [18] involving 75 manufacturing companies listed on the Indonesia Stock Exchange found that intellectual capital does not affect the financial performance of the company.

From the above description, the first hypothesis of this research is:"Environmental Performance and Intellectual Capital affect the Financial Performance of the company either simultaneously or partially."

\section{Corporate Social Responsibility Disclosure}

With the concept of corporate social responsibility (CSR), the company is responsible not only for its financial performance but also its social performance as well as its environment [49] and can be seen as an important part of corporate strategy [50]. Although in its implementation there are various paradigms [51], ranging from social, 
environmental and reputation driven paradigms, compliance to a "compliance plus, internal driven" paradigm, but CSR programs must be disclosed by the company to stakeholders, both as an effort to show the company's concern for its social, economic and environmental aspects [52] as well as efforts to comply with applicable accounting standards. Disclosure is defined as the provision of additional information [53] to the reporting parties, and with such additional information, and according to [54], it will assist their users in economic decision-making.

Companies that disclose their programs and environmental performance in annual reports, let alone disclosed with a single report that contains social performance, will be able to become a marketing tool for companies to influence sales that will impact on the profits earned by the company. Further, this will affect the stock market price or increase the value of the company [55]. In the relationship between environmental performance and intellectual capital with the company's financial performance, CSR disclosure is expected to positively affect the company's financial performance in the presence of good CSR disclosure. Based on this description, the second hypothesis is:

"CSR disclosure can moderate the relationship between environmental performance and Intellectual Capital with Corporate Financial Performance."

From the description and the two hypotheses presented above, we can illustrate the conceptual framework in this study as follows:

Figure 2.1: Conceptual Framework

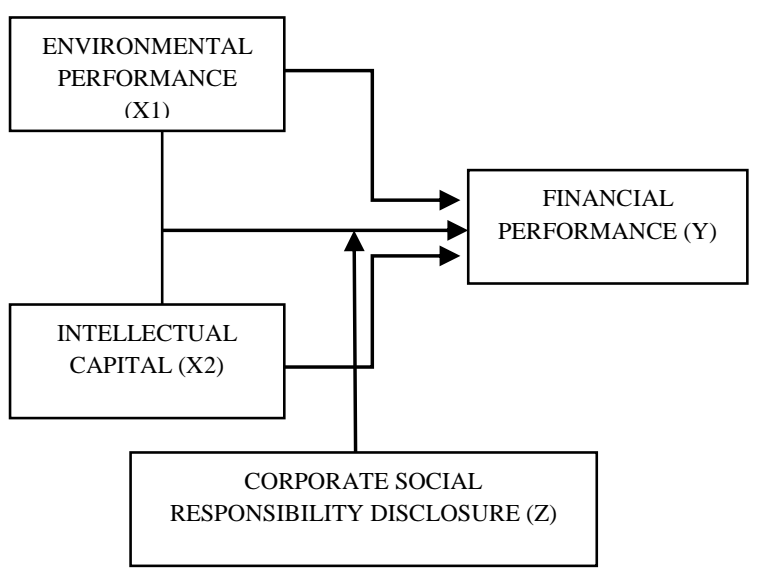

\section{RESEARCH METHOD}

\section{A. Population and Sample}

The population in the study are manufacturing companies listed on the BEI during 2012-2014. The number is 143 companies. From the selected number of samples by using purposive sampling method with criteria that the company discloses its social responsibility information in the annual report, the company follows the PROPER program and the company must have a positive profit during the study period. Of the total population, only 14 companies are selected. Since the data taken is over a 3 -year period, the unit of analysis is 42 .

\section{B. Operational Definition and Variable Measurement}

There are four variables analyzed in this research, that is:

1) Financial performance

Financial performance is defined as the achievement or ability of the company in managing and allocating its resources from the financial side. In this study, the company's financial performance is measured by using Return on Assets (ROA). The formula is:

$$
\mathrm{ROA}=\frac{\text { Net Income After Taxes }}{\text { Total Aset }} \times 100
$$

\section{2) Environmental Performance}

Environmental performance is defined as the achievement of the company in conducting its operational activities related to the environment. This achievement is measured by the company's performance in following the PROPER program implemented by the Ministry of Environment (KLH). This performance is shown in the PROPER ranking that ranks companies in the following five categories:

Table 3.1:

Ranking Categories of PROPER

\begin{tabular}{|l|l|c|}
\hline \multicolumn{1}{|c|}{ Color } & \multicolumn{1}{c|}{ Rating } & Interval \\
\hline Gold & Very very good & 5 \\
\hline Green & Very good & 4 \\
\hline Blue & Good & 3 \\
\hline Red & Bad & 2 \\
\hline Black & Very Bad & 1 \\
\hline
\end{tabular}

3) Intelectual Capital

Intellectual capital is defined as an intangible asset in the form of information, knowledge and other capabilities that are implemented in order to create a 
competitive advantage of the company. In this study, intellectual capital is measured by using the valueadded concept created by Public, VAIC тм (Value Added Intellectual Coefficient). Intellectual Capital is the performance of intellectual capital measured by value added created by capital employed (VACA), human capital (VAHU), and structural capital (STVA).

Formulation of calculations VAICTM are asfollows:

1. Calculating Value Added

$$
\mathrm{VA}=\mathrm{OUT}-\mathrm{IN}
$$

where:

OUT: Total sales and other revenue.IN: Expenses and expenses (other than personal expenses).

Value Added (VA): Difference between Output and Input

2. Calculating value of VACA, VAHU, STVA

Value Added Capital Employed(VACA): Ratio of $\mathrm{VA}$ to $\mathrm{CE}$. This ratio shows the contribution made by each unit of $\mathrm{CE}$ to the value added organization. The value of $\mathrm{CE}$ is the net book value of the book.

$$
\mathrm{VACA}=\mathrm{VA} / \mathrm{CE}
$$

where:

Capital Employed (CE): Available funds (equity, net income).

Value Added Human Capital (VAHU): Ratio of VA to HC. This ratio shows the contribution made by each rupiah invested in $\mathrm{HC}$ to the value added of the organization. $\mathrm{HC}$ value is the salary of the employee.

$$
\mathrm{VAHU}=\mathrm{VA} / \mathrm{HC}
$$

where:

Human Capital (HC): Employee expenses.

Structural Capital Value Added (STVA): Ratio of $\mathrm{SC}$ to VA. This ratio measures the amount of SC needed to generate 1 rupiah from the VA and is an indication of how SC's success is in value creation. $\mathrm{SC}$ value is the difference between VA value with $\mathrm{HC}$ value.

$$
\text { STVA }=\text { SC/VA }
$$

Value Added Intellectual Coefficient (VAICTM): Indicates the intellectual ability of the organization.

$$
\mathrm{VAIC}^{\mathrm{TM}}=\mathrm{VACA}+\mathrm{VAHU}
$$

$$
+ \text { STVA }
$$

\section{4) CSR Disclosure}

CSR disclosure is defined as providing information about the performance achieved by the company in the environmental field. This variable is measured using CSR Index (CSRI) which shows the relative disclosure of each sample company over its social disclosure as used by [56]. The approach to calculating CSRI basically uses a dichotomy i.e. each CSR item in a research instrument is rated one if it is disclosed, and a value of 0 if not disclosed as done by [57]. The CSRI calculation formula is as follows:

$$
C S R I_{j}=\frac{\sum X_{i j}}{n_{j}}
$$

where:

CSRIj $=$ Corporate Social Responsibility Disclosureindex company $\mathrm{j}$

nj $\quad=$ amount item for company $\mathrm{j}, \mathrm{nj} \leq 78$

$\mathrm{Xij}=$ variable dummy $: 1:$ if item $\mathrm{i}$ disclosed; $0:$ if itemi do not disclosed as such, $0 \leq \mathrm{CSRIj} 1$

\section{Method of Analysis}

Before testing the hypothesis, some data analysis is done first to ensure the feasibility of data for hypothesis testing. The analyzes include descriptive analysis and Classic Assumption Test which includes Normality Test, Multicollinearity Test, Autocorrelation Test, and Heteroscedasticity. After the test results indicate the feasibility of the data, then the hypothesis testing is done.

Hypothesis testing is conducted to determine the effect of environmental performance and intellectual capital on the financial performance of the company, either partially or simultaneously. The test was performed by using multiple linear regression analysis using the following partial equation:

$$
\mathrm{Y} 1=\mathrm{a}+\beta 1 \mathrm{X} 1+\beta 2 \mathrm{X} 2+\varepsilon
$$

To see whether or not the moderating effect of CSR disclousure on the relationship between environmental performance and intellectual capital to financial performance, we use regression model with interaction with equation as follows:

$$
\begin{aligned}
& \mathrm{Z}_{3}=\mathrm{a}+\beta 1 \mathrm{X} 1+\beta 2 \mathrm{X} 2+\mathrm{e} \\
& |\mathrm{e}|=\mathrm{a}+\beta 1 \mathrm{Y}
\end{aligned}
$$

where:

$$
\begin{aligned}
\mathrm{Y} & =\text { Company's Financial Performance } \\
\alpha & =\text { Constanta } \\
|\mathrm{e}| & =\text { Coefficient Regression } \\
\mathrm{X}_{1} & =\text { Environmental Performance } \\
\mathrm{X}_{2} & =\text { Intellectual Capital } \\
\mathrm{Z} & =\text { Moderating variable (CSR disclousure) } \\
\mathrm{e} & =\text { Eror Term }
\end{aligned}
$$

\section{RESULTS AND DISCUSSIONS}

A. Analysis of Research Results 


\section{1) Descriptive Statistics Analysis}

The results of descriptive statistical analysis can be seen in table 4-1 below.

Table 4.1:

Descriptive Statistics

\begin{tabular}{|l|r|r|r|r|r|}
\hline & N & Minimum & Maximum & Mean & $\begin{array}{r}\text { Standard } \\
\text { Deviation }\end{array}$ \\
\hline KL & 42 & 2 & 5 & 3.17 & .660 \\
ROA & 42 & 1.04 & 51.51 & 16.7762 & 11.94930 \\
VAIC & 42 & 1.65 & 21.50 & 6.1181 & 4.86588 \\
CSR & 42 & 14.10 & 44.87 & 30.8917 & 9.55659 \\
Disclosure & & & & & \\
Valid N & 42 & & & & \\
(listwise) & & & \multicolumn{5}{|c|}{ Source: Results of SPSS } \\
\hline
\end{tabular}

Based on the above table that the company's financial performance as measured by ROA has a minimum value of 1.04 and a maximum value of 51.51, while the standard deviation of 11.94930 and the average value of 16.7762. This means that the financial performance of the companies studied during the study period is low. Furthermore, the environmental performance has a minimum value of 2 and a maximum value of 5 , while the standard deviation of 0.66 and the average value of 3.17 . Thus, the environmental performance of the firms studied is moderate. Intellectual capital measured by Value Added Intellectual Capital (VAIC) has a minimum value of 1.65 and a maximum value of 21.50 , while the standard deviation of 4.86588 and the average value is only 6.1181 , which means that the value of intellectual capital is low. Finally, CSR disclosure as a moderating variable has a minimum value of 14.10 and a maximum value of 44.87 , while the standard deviation value is 9.55659 and an average value of 30.8917. This indicates that the disclosure of corporate social responsibility is high.

\section{2) The Results of Classical Assumption Tests}

Prior to hypothesis testing, the first classical assumption test is used to ensure the matching of the data used. This test includes normality test, multicollinearity test, heteroscedasticity test and autocorrelation test. The results show that the data is normally distributed (either by graphical test or by Kolmogorov-Smirnov test) Furthermore multicollinearity test results are known that there is no symptom of multicollinearity in the independent variable. The result of heteroskedasticity test by using scatterplot graph shows that there are no symptoms of heteroskedasticity on regression model in this research. Finally, the autocorrelation test result also shows that there are no symptoms of autocorrelation.

\section{3) Hypothesis Testing Results 1}

Testing of hypothesis 1 is done by using multiple linear regression to see the effect of environmental performance and intellectual capital to financial performance can be seen in the tables and the following description.

\section{4) Coefficient of Determination Test (R2)}

The determination coefficient test (R2) is used to describe the ability of the model to explain the variations that occur in the dependent variable [58]. The coefficient of determination (R2) is expressed as a percentage. A value that speaks one means that the independent variable provides almost all the information needed to predict the variation of the dependent variable. The value of coefficient of determination (R2) can be seen in table 4.2 below:

Table 4.2: Coefficient Determination

\begin{tabular}{|l|r|r|r|r|}
\hline Model & R & R Square & $\begin{array}{c}\text { Adjusted R } \\
\text { Square }\end{array}$ & $\begin{array}{r}\text { Std. Error of } \\
\text { the Estimate }\end{array}$ \\
\hline 1 & $.514^{\mathrm{a}}$ & .264 & .226 & .65295 \\
\hline
\end{tabular}

Based on the above table it is known that the correlation coefficient $(\mathrm{R})$ of 0.514 or $51.4 \%$ indicates that the level of relationship between independent variables (environmental performance and intellectual capital) with the dependent variable (financial performance) is quite close, that is above $50 \%$. Furthermore from the table is also known R Square value of 0.264 or $26.4 \%$ means $26.4 \%$ variable corporate financial performance is influenced by environmental performance and intellectual capital, while the remaining $73.6 \%$ influenced by factors other factors outside the model.

\section{5) Result F Test}

$\mathrm{F}$ test is conducted to determine the simultaneous effect of all independent variables, namely environmental performance and intellectual capital to the company's financial performance. The results of this $F$ test are shown in Table 4.3 below:

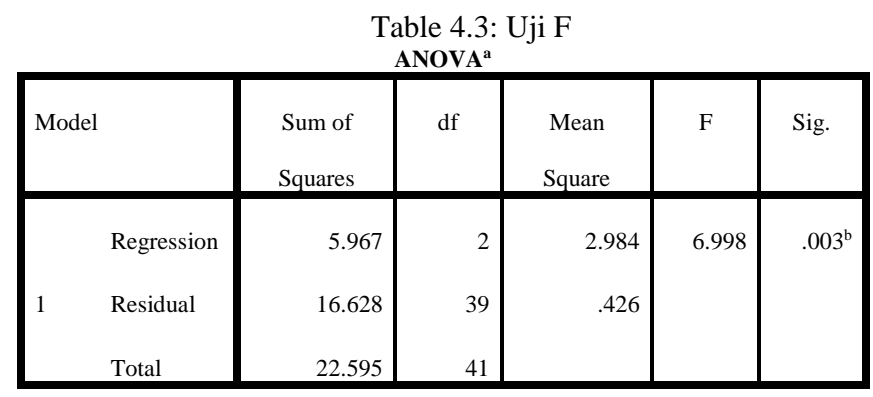

a. Dependent Variable: LnROA

b. Predictors: (Constant), KL, LnVAIC 
Based on the above table that both independent variables, namely environmental performance and intellectual capital have a significant influence simultaneously on the dependent variable. This can be proved from the value of $\mathrm{F}$ arithmetic of 6.998 with a significance of 0.003 . The F-value is greater than F-table of 1.72. If the value of significance below 0.05 or $5 \%$ then the regression can be used to predict the company's financial performance or it can be said that environmental performance and intellectual capital have a positive and significant impact on the financial performance of the company.

\section{6) Results of t-Test}

T-test is conducted to test the partial influence of each independent variable of environmental performance and intellectual capital on company financial performance. T-test results can be seen in Table 4.4 below:

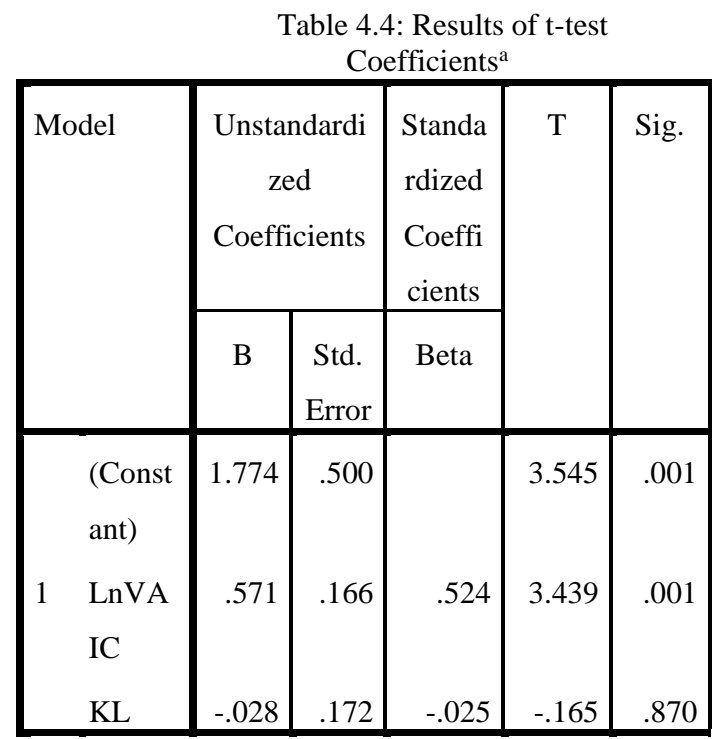

a. Dependent Variable: LnROA

Source: Results of SPSS

Based on table 4.4 then the regression results show that the influence of each variable of environmental performance and intellectual capital to the company's financial performance is different. The t-value for the environmental performance variable is -0.165 (compared with the value of t-table 1.68), as well as the significance value of $0.870>0.05$, so it can be concluded that the environmental performance has no effect on the financial performance of the company. While the variable of intellectual capital has a t-value which is much bigger (3.3439 compared with the value of t-table: 1680) which is also supported by the significance value of $0.001<0.050$ which indicates that the intellectual capital variable positively and significantly influence the financial performance of the company.

\section{7) Hypothesis Testing Results 2}

a) Relationship of Environmental Performance and Financial Performance is moderated by CSR Disclosure.

The test results in the form of the effect of environmental performance on financial performance moderated by CSR disclosure on manufacturing companies listed on the Stock Exchange period 2012-2014 are shown in Table 4.5 below:

Table 4.5: Regression Analysis Results Coefficients $^{\mathrm{a}}$

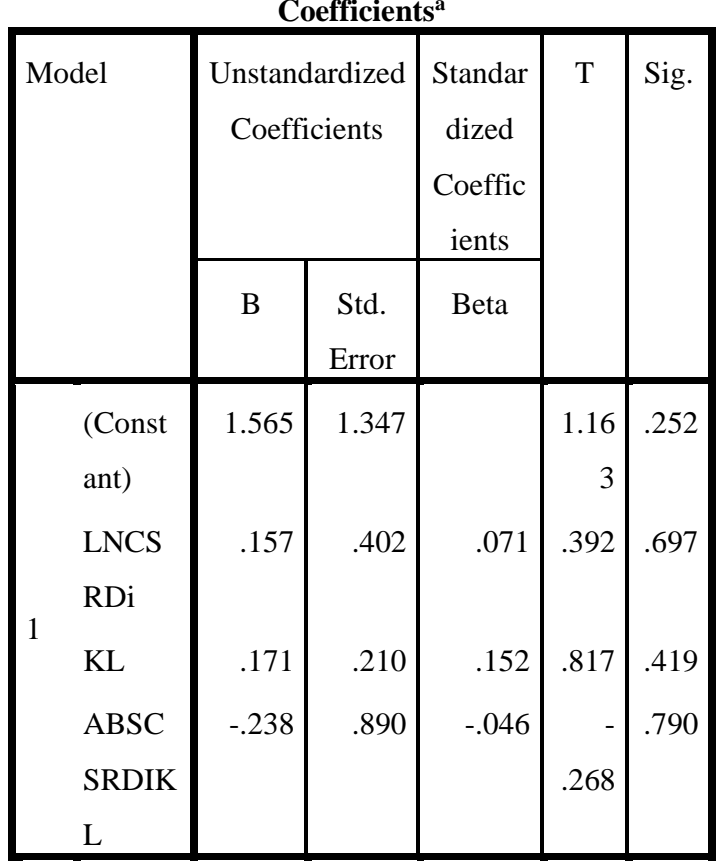

a. Dependent Variable: LnROA

Source: Results of SPSS

Based on the test results shown in Table 4.5 it is known that the variable difference (ABSCSRDiKL) has the significance of $0.790>0.05$, so it can be concluded that CSR disclosure can not moderate the relationship between environmental performance and financial performance of the company.

\section{b) The relationship between Intellectual Capital and Financial Performance is moderated by CSR Disclosure. \\ The test results on the effect of CSR Disclosure} moderation on the relationship between intellectual capital variables and financial performance on manufacturing companies listed on the BEI period 2012-2014 are shown in Table 4.6 below: 
Table 4.6: Regression Analysis Results Coefficients $^{\mathrm{a}}$

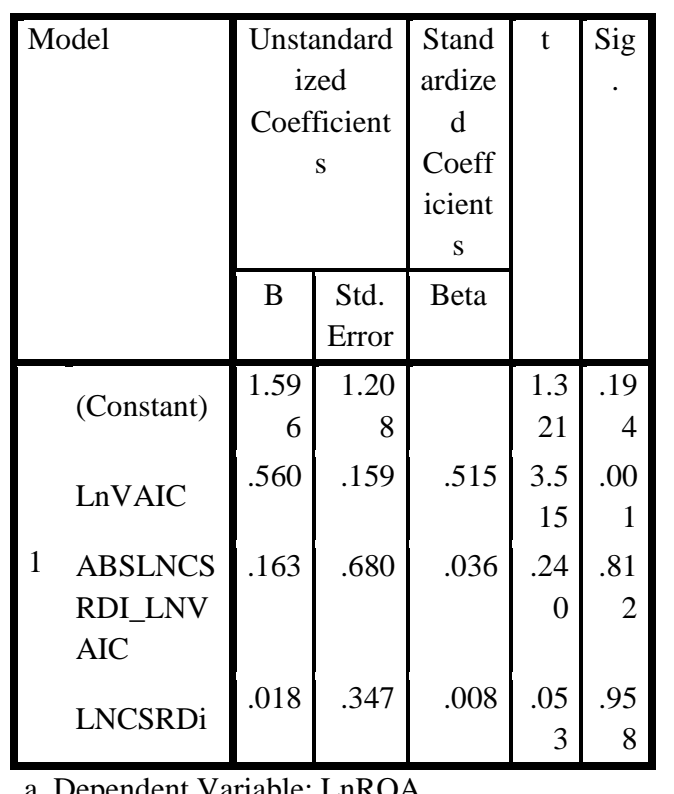

Source: Results of SPSS

The result of linear regression analysis with the moderating variable of CSR disclosure shown in Table 4.6 shows that the variable of ABSLNCSRDi_LNVAIC has significance of $0.812>0.05$, so it can be concluded that CSR disclosure can not moderate the relationship between intellectual capital and the company's financial performance.

\section{B. Discussions}

1) The influence of environmental performance on the company's financial performance

The measure of environmental performance in this study was measured using PROPER issued by the Ministry of Environment (KLH). With PROPER is expected to care about the company around the company where the company stands. If a company in following PROPER gets a good rating then the sustainability of the company will also be good because the sustainability of a company also depends from its stakeholders not only on improving financial performance alone. Although on average the number of firms gets more blue ratings indicates that they have been concerned about the environment, but the results of hypothesis testing show that environmental performance has no effect on financial performance. This means that the blue rating obtained by the company has not been able to improve the company's positive image. Though the positive image of the company is very important in order to get a good legitimacy from the community so that will ensure the sustainability of the company in the future.
This finding also shows that the environmental performance variable is not a factor affecting the company's financial performance. For example, in 2013 PT Indofood SuksesMakmur is rated PROPER 3 or blue but has a low financial performance of 4.38, while for PT Multi Bintang Indonesia having PROPER 2 or red actually has a higher financial performance of 35.74. It can also be interpreted that investors have not paid attention to environmental performance issues that are actually important for the sustainability of a company, investors are only looking at financial performance alone.

The findings of this study are not in line with the findings of research conducted by [42], [59], and [60] which indicate a significant relationship between environmental performance and financial performance. In contrast, the results of the research are consistent with the research conducted by [14] and [61] who found no significant relationship between environmental performance and financial performance.

2) The influence of intellectual capital on the company's financial performance

The company's attention to intellectual capital management in recent years has been increasing, due to the realization that intellectual capital is the foundation for the company to grow and have advantages over other companies. The test result of intellectual capital variable influence with $\mathrm{Ln}$ Value added intellectual capital (LNVAIC) shows the positive and significant influence to financial performance at manufacturing company listed in Indonesia Stock Exchange period 2012-2014 period. This result is indicated by the value of $t$ arithmetic (3.3439) $>\mathrm{t}$ table (1.680) and the significance value of $0.01<0.05$. These results indicate that the greater the value of intellectual capital of a company will be the higher the company's financial performance. This finding is consistent with the findings of [23], [22], and [62] and not in accordance with [19], and [18] studies.

\section{3) The role of CSR disclosure as a moderating variable}

The view that disclosure of a high CSR program is expected to be a consideration for investors to not only see the company's performance financially but also the environmental performance is not proven in this research. This is evident from the results of tests showing that CSR disclousurecan not moderate the relationship between environmental performance and intellectual capital with financial performance on manufacturing companies listed in Indonesia Stock Exchange period 2012-2014. These results 
ultimately lead to the conclusion that CSR disclosure variable is not able to strengthen the relationship between environmental performance and intellectual capital with the company's financial performance. Although CSR disclosure is part of the company's strategy to provide a positive image to the public that the company is not only pursuing profit, but also paying attention to the environment, but behind it the CSR implementation itself will increase the company's operating costs, resulting in lower net profit. This means that improvements to corporate image does not make the company's profit has increased.

\section{CONCLUSIONS, LIMITATIONS, AND SUGGESTIONS}

\section{A. Conclusions}

Based on the discussion of the above research results, it can be concluded that:

1. Environmental performance and intellectual capital simultaneously can affect financial performance at manufacturing companies listed in Indonesia Stock Exchange period 2012-2014. It can be interpreted that the higher the environmental performance and the intellectual capital then the better the financial performance of the company. But when tested partially it is not all independent variables affect the financial performance. Only intellectual capital has a significant effect on financial performance, while environmental performance has no significant effect on the financial performance of manufacturing companies listed on Indonesia Stock Exchange in 2012-2014.

2. CSR disclosure is not able to moderate the relationship between environmental performance and intellectual capital with financial performance. This means that in the manufacturing companies listed on the Indonesia Stock Exchange in 2012-2014, CSR disclosure in research can not raise the influence of environmental performance and intellectual capital expect financial performance or not serve as moderating variable.

\section{B. Limitations of Research}

There are some limitations in this research, which are as follows:

1. In this study, the sample used only manufacturing companies, so the company sampled can not represent the entire company in Indonesia.

2. The period of time taken in this study only in 20122014 , so the condition can not be generalized to the results of existing research.
3. The variable of financial performance is measured only by ROA.

\section{Suggestions}

Based on the limitations of the research as stated above it is suggested to the further researches as follows:

1. To increase the number and scope of research sample, not only manufacturing companies but also companies in other fields such as mining and oil and gas companies.

2. To increase or extend the study period for example 5 years to get better results.

3. To add or try other financial performance measurement tools, for example by using Return on Equity, Gross profit margin, Earning per share, and other financial performance measurement.

\section{REFERENCES}

[1] Horngren, C. T., G. L., Sundem, W. O., Stratton, D., Burgstahler, and J., Schatzberg, 2008, Introduction to Management Accounting, $14^{\text {th }}$ edition, NY: Pearson Prentice-Hall.

[2] Sutrisno, 2009, ManajemenKeuangan: Teori, Konsep, danAplikasi, Yogyakarta: Ekonisia.

[3] Simons, R., 2000. Performance Measurement and Control Systems for Implementing Strategy, NY: Prentice-Hall.

[4] Meigs, F. M., J. R., Williams, S. F., Haka, and M. S., Bettner, 2001, Financial Accounting, $10^{\text {th }}$ Edition, NY: McGraw-Hill.

[5] Collier, P., M., 2012, Accounting for Managers Interpreting Accounting Information for Decision Making, $4^{\text {th }}$ edition, A John Wiley and Sons, Ltd.

[6] Dybvig, P., H. dan M. Warachka, 2010, “Tobin's Q Does Not Measure Performance: Theory, Empirics, and Alternative Measures", Working Paper, November 2010

[7] Husnan, S., 2004, Dasar-dasarTeoriPortofoliodanAnalisisSekuritas, Yogyakarta: BPFE.

[8] Helfert, E. A., 1996, TeknikAnalisisKeuangan, Jakarta: Erlangga.

[9] Stoner, J. A. F., R. E., Freeman, and D. L., Gilbert, 1996, Manajemen, Jakarta: Prenhallindo.

[10] Al-Majali, A. Y., S. A., Alamro, and Y. Z., Al-Soub, 2012, "Factors Affecting the Financial Performance of Jordanian Insurance Companies Listed at Amman Stock Exchange," Journal of Management Research, Vol. 4, No. 2, pp. 266 - 290.

[11] Zeitun, R., and G. G., Tian, 2007, "Capital Structure and Corporate Performance," Australian Accounting, Business and Finance Journal, 1 (4), pp.

[12] Pflieger, J., M., Fischer, T., Kupfer, and P., Eyerer, 2005. "The contribution of life cycle assessment to global sustainability reporting of Organization". Management of Environmental. Vol. 16 , No.2. 
[13] Sawarjuwono, T. dan A. P., Kadir, 2003, "Intellectual Capital: Perlakuan, PengukurandanPelaporan (Sebuah Library Research)”, JurnalAkuntansidanKeuangan. Vol 5, No. 1, 31-51.

[14] Sarumpaet, S., 2005, "The Relationship Between Environmental Performance and financial performance of Indonesian companies",JurnalAkuntansidanKeuangan, Volume 7, Nomor 2, Universitas Kristen Petra.

[15] Rakhiemah, N. A., and Agustia, D., (2007), "PengaruhKinerjaLinkunganterhadap Corporate Social Responsibility (CSR) Disclosure danKinerjaFinansialPerusahaanManufaktur yang Terdaftar di Bursa Efek Indonesia",SimposiumNasionalAkuntansi, 12, Palembang.

[16] Malinda, F., 2012, "Pengaruh Environmental Performance terhadap Financial Perfromancepada Perusahaan Manufakur yang Terdaftar di Bursa Efek Indonesia Tahun 2010-2011, Working Paper,

$$
\text { Fitriani, }
$$$$
\text { Anis. }
$$

"PengaruhKinerjaLingkungandanBiayaLingkunganTerhadapKinerj aKeuanganPada BUMN”. JurnalImuManajemen, Vol. 1 No. 1, Januari : $137-148$

[18] Adhita, S. N., and S., Titiek, 2014, "AnalisisPengaruh Corporate Social Responsibility, Intellectual Capital, danKinerjaLingkunganManufaktur yang Terdaftar di Bursa Efek Indonesia", Prosiding Seminar Nasional Multi DisiplinIlmu\& Call for Papers Unisbank, ISBN: 978-979-3649-81-8.

[19] Kuryanto, B., and M. Syafruddin, 2008, "Pengaruh Modal IntelektualTerhadapKinerja Perusahaan”, SimposiumNasionalAkuntansi, 11.

[20] Mohammad, J. A., 2005, "Intellectual Capital Disclosure and Market Capitalization", Journal of Intellectual Capital, 6 (3), pp. 397 416.

[21] Tan, H.P., Plowman, D., and Hancock, P., 2007, "Intellectual Capital and Financial Returns of Companies", Journal of Intellectual Capital, Vol. 8, No. 1, pp: 76-95.

[22] Baroroh, N., 2013, "AnalisisPengaruh Modal IntelektualterhadapKinerjaKeuangan Perusahaan Manufaktur di Indonesia", JurnalDinamikaAkuntansi, Vol. 5, No. 2, September, pp. $172-182$.

[23] Mahfoudh, A. K. Al-Musali, and K. N. I. Ku Ismail, 2014, "Intellectual Capital and Its Effect on Financial Performance of Banks: Evidence from Saudi Arabia”, Procedia - Social and Behavioral Science, 164, pp. 201-207.

[24] Wahyuni, G. A., Yuniarta, and N. K., Sinarwati, 2015, "PengaruhIntelectual Capital, Corporate Social Responsibility Dan Good Corporate Governance TerhadapKinerjaKeuangan (StudiKasusPada Perusahaan BUMN yang Terdaftar di Bursa Efek Indonesia PadaTahun 2011-2013)". E-JournalS1 Ak, Volume 3, No. 1, UniversitasPendidikanGaneshaJurusanAkuntansi Program $\mathrm{S} 1$.

[25] Wheelen, T. I., and J. D., Hunger, 2002, Strategic Management and Business Policy, $8^{\text {th }}$ Edition, NJ: Prentice Hall.

[26] Van Horne, and Wachowiz, Jr., 1998, Financial Statement Analysis, Mexico: Prentice-Hall.

[27] Munawir, S., 2000, AnalisisLaporanKeuangan, EdisiKeempat,

Yogyakarta: Liberty

[28] Sayekti, Yosefa. "PENGARUH CSR DISCLOSURE TERHADAP EARNING RESPONSE COEFFICIENT (SuatuStudiEmpirisPada
Perusahaan yang Terdaftar Di Bursa Efek Jakarta)" SimposiumNasionalAkuntansi X Unhas Makassar 26-27 Juli 2007.

[29] Hadi, Nor, 2011, Corporate Social Responsibility," Yogyakarta: Grahailmu.

[30] Kavitha, W. and Anita P. 2011. "Disclosure About CSR Practises: A Literature Review".The IUP Journal of Corporate Governance, Vol. X No. 1

[31] Siregar, S. V., and L. Dahlia, 2008, "PengaruhCSR DisclosureterhadapEarning Response Ecofficient(SuatuEmpirisPada Perusahaanyang Terdaftar di Bursa Efek Jakarta).” SimposiumNasionalAkuntansi XI.Pontianak , 23- 26 Juli.

[32] Basamalah, A. S., and J. Jermias (2005), "Social and Environmental Reporting and Auditing in Indonesia: Maintaining Organizational Legitimacy?",GadjahMada International Journal of Business, January-April 2005, Vol. 7, No. 1, pp. 109 - 127.

[33] Kuntluru, S., V. R., Muppani, and M. A. Ali Khan, 2008, "Financial Performance of Foreign and Domestic Owned Companies in India", Journal of Asia-Pasific Business, Vol. 9, Issue 1, pp 28-54.

[34] Sembiring, Eddy Rismanda. 2005. Karakteristik Perusahaan danPengungkapanTanggungJawabSosial :StudiEmpirispada Perusahaan yang Tercatat di Bursa Efek Jakarta. SimposiumNasionalAkuntansi VIII. Solo.

[35] Ja'far, S, Muhammad dan A. D., Amalia, 2006 , "PengaruhDoronganManajemenLingkungan, ManajemenLingkunganProaktifdanKinerjaLingkunganPublikEnvir onmental Reporting", SimposiumNasionalAkuntansi IX.

[36] Sudiyanto, B., 2010, “AnalisisPengaruh Dana PihakKetiga, BOPO, CAR dan LDR terhadapKinerjaKeuanganpadaSektorPerbankan Yang Go Public di Bursa Efek Indonesia (BEI) Periode 20052008", JurnalDinamikaKeuangandanPerbankan, Vol. 2 No. 2.

[37] Sukarno and Syaichu, 2006, "AnalisisFaktor-Faktor Yang MempengaruhiKinerja Bank Umum di Indonesia", JurnalStudiManajemendanOrganisasi, Vol. 3, No. 2, Juli.

[38] Mawardi, W., 2005, “AnalisisFaktor-Faktor Yang MempengaruhiKinerjaKeuangan Bank Umum di Indonesia (StudiKasuspada Bank Umumdengan Total AsetKurangdari 1 Triliun)", JurnalBisnisStrategi. (Online), Vol. 14, No. 1.

[39] Luktasari, Y. P., and A. Kartika, 2014, “AnalisisPengaruh Dana PihakKetiga, BOPO, CAR, LDR, dan NPL terhadapKinerjaKeuanganpadaSektorPerbankan yang Terdaftar di Bursa Efek Indonesia”, Jurnal AMIK JTC, Vol. 11 No. 4.

[40] Figge, F, and T. Hahn, 2004, "Sustainable value added-measuring corporate contributions to sustainability beyond eco-efficiency", Ecological Economics, 48 (2), pp. 173-187.

[41] Al-Tuwaijri, S.A., T.E., Christensen, dan K.E., Hughes II (2004), “The Relations Among Environmental Disclosure, Environmental Performance, and Economic Performance: A Simultaneous Equations Approach", Accounting, Organizations, and Society, 29: 447-471.

[42] Suratno, 2006, Pengaruh Environmental Performance Terhadap Environmental Disclosure dan Economic Performance", Thesis, (tidakdipublikasi).

[43] Stewart, A. T., 1997, Intellectual Capital, The New Wealth of Organizations, New York: Bantam Doubleday Publishing. 
[44] Lankoski, Leena (2000), "Determinants of Environmental Profit, An Analysis of the Firm-level Relationship between Environmental Performance and Economic Performance", Doctoral Dissertations, Helsinki: University of Technology.

[45] Pintea, M., L. Stance, S. Achim, dan I. Pop (2014), "Is there a Connection Among Environmental and Financial Perfromance of a Company in Developing Countries?, Evidence from Romania" Procedia Economics and Finance, Volume 15, pp. 822-829.

[46] Bontis, N. (2004), "National Intellectual Capital Index: A United Nations Initiative for the Arab Region", Journal of Intellectual Capital, Vo. 5, No. 1, pp: 13-39.

[47] Nasih, M. (2005), "PeranStrategis Intellectual Capital sebagaiVariabelAntaraPengaruhFinancial Capital terhadapKinerja Perusahaan",Disertasi" " (tidakdipublikasi, Surabaya: PascasarjanaUnair.

[48] Gene M. G. and A. B., Krueger, 1995 "Economic Growth and the Environment". The Quarterly Journal of Economics, Vol. 110, No. 2. (May, 1995), pp. 353-377

[49] Ulum, Ihyaul, I. Ghozalidan A. Chariri, (2008).“Intellectual Capital Dan KinerjaKeuangan Perusahaan; SuatuAnalisisDenganPendekatan Partial Least Squares".SimposiumNasionalAkuntansi XI: Pontianak, 23-25 Juli 2008.

[50] Petty, P. and J. Guthrie, 2000. "Intellectual capital literature review: measurement, reporting and management". Journal of Intellectual Capital. Vol. 1 No. 2. Pp. 155-75.

[51] Dahlsrud 2006. How Corporate Social Responsibility Is Defined: An Analysis of 37 Definitions. Corporate Social Responsibility and Environmental Management, Vol. 15, No.1. (January 2008), pp. 113 .

[52] Paul, Catherine J Morrison. 2006. “Corporate Social Responsibility and Economic Performance". DepartmenOf Agricultural and Resource Economics University Of California.

[53] Deegan, C, 2002, The Legitimissing Effect of social and Environmental Disclosure- A Theoritical Foundation, Accounting, Auditing, and Accountability Journal, Vol. 15, No. 3

[54] Nurhudha, A.S., dan S. Titiek (2015), "AnalisisPengaruhCorporate Social Responsibility, Intellectual Capital, KinerjaLingkunganterhadapKinerjaKeuangan Perusahaan Manufaktur Yang Terdaftar di Bursa Efek Indonesia", Students Journal of Accounting and Banking, Vol. 4, No. 1.

[55] Verrecchia, Robert, E., (1983), "Discretionary Disclosure", Journal of Accounting and Economics, 5, pp 179- 194.

[56] Zuhroh, D., and I. P. P. H., Sukmawati, 2003, "AnalisisPengaruhLuasPengungkapanSosialdalamLaporanTahunan Perusahaan terhadapReaksi Investor (StudiKasuspada PerusahaanPerusahaan high-Profile di BEJ)", SimposiumNasionalAkuntansi, VI, hal. 1314 - 1341.

[57] Haniffa, R.M., and T.E. Cooke, 2005, "The Impact of Culture and Governance on Corporate Social Reporting", Journal of Accounting and Public Policy, 24, pp. 391-430.

[58] Ghozali, I., 2005, Analisis Multivariate Dengan Program SPSS,

Semarang: Badan PenerbitUniversitasDiponegoro.

[59] Bruggen, A., Vergauwem, P. and Dao Mai. 2009. "Determinants of intellectual capital disclosure: evidence from Australia". Management Decision Vol. 47 No. 2, 2009 pp. 233-245.
[60] Mirela-Oana, P., L. Stanca, S. A., Achim and I., Pop, 2014, "I There a Connection Among Environmental and Financial Performance in Developing Countries ? Evidence from Romania", Procedia Economics and Finance, 15: $822-829$.

$$
\text { Sudaryanto, }
$$

"PengaruhKinerjaLingkunganTerhadapKinerjaFinansial Perusahaan Dengan Corporate Social Responsibility Disclosure sebagaiVariabel Intervening Pada Perusahaan Manufaktur Yang Terdaftar Di BEI Tahun 2007-2009”,JurnalAkuntansidan Auditing, UniversitasDiponegoro.

[62] Suratno, I., Bondan, dan S., Mutmainah (2006), "PengaruhEnvironmentalPerformance

terhadapEnvironmentalDisclosure danEconomic Performance (StudiEmpirisPada Perusahaan Manufaktur yang Terdaftar di BEJ Periode 2001 - 2004)", SimposiumNasionalAkuntansi 9 , Padang: 23 - 26 Agustus. 